\title{
Permian woods with preserved primary structures from the southeast of Brazil (Irati Formation, Paraná basin)
}

\author{
Rafael Souza Faria $^{1}$ - Fresia Ricardi-Branco ${ }^{1}$ (D) - Rosemarie Rohn ${ }^{2}$. \\ Marcelo Adorna Fernandes ${ }^{3} \cdot$ Isabel Christiano-De-Souza ${ }^{1}$
}

Received: 11 September 2017 / Revised: 27 November 2017 / Accepted: 6 February 2018 / Published online: 24 March 2018

(C) Senckenberg Gesellschaft für Naturforschung and Springer-Verlag GmbH Germany, part of Springer Nature 2018

\begin{abstract}
This research described fossil woods with preserved pith and primary xylem from strata of the Irati Formation (Artinskian) of the Paraná Basin (southeastern Brazil). The three specimens studied are all related to the Coniferales and include the following taxa: Solenopitys paulistana Kräusel, Atlanticoxylon ibiratinum n. sp. and Abietopitys sp. Kräusel. Solenopitys paulistana represents a species with a solid, heterocellular pith with a peripheral secretory canal system. Atlanticoxylon ibiratinum n. sp. has a lacunose, heterocelular pith with "nests" of sclereids, with a central secretory canal and a peripheral system of canals. Abietopitys sp. has a solid, lobed, homocelular pith associated with a secondary xylem containing cross-fields with
\end{abstract}

Fresia Ricardi-Branco

fresia@ige.unicamp.br

Rafael Souza Faria

writetofaria@gmail.com

Rosemarie Rohn

rohn@rc.unesp.br

Marcelo Adorna Fernandes

marcelicno@yahoo.com.br

Isabel Christiano-De-Souza

isabel.cortez@ige.unicamp.br

1 Departament of Geology and Natural Resources, Institure of Geosciences, University of Campinas, Carlos Gomes, 250, Campinas 13083-855, Brazil

2 Department of Applied Geology, University of the State of São Paulo - Unesp Rio Claro, Av. 24a, 1515, Rio Claro, São Paulo, Brazil

3 Departament of Ecology and Evolutive Biology, Federal University of São Carlos, Washington Luiz Highway, 235, São Carlos, São Paulo, Brazil non-contiguous pits (abietoid vascular rays). Xeromorphic features observed in these specimens, such as a pith with groups of sclereids and false growth rings, may be related to the depositional environment of the Irati Formation. The specific factor triggering the xeromorphy has not yet been determined, but the present study corroborates clearly the sedimentary evidence of dry conditions during the deposition of the Irati Formation, as seen in the 30-m-thick carbonate layer extending through four South American countries.

Keywords Fossil wood $\cdot$ Coniferales $\cdot$ Xeromorphy $\cdot$ Irati Formation $\cdot$ Permian

\section{Introduction}

During the Permian, the floristic elements of Gondwanaland were typically characterised by spermatophytes, such as the glossopterids and conifers, with their fossil record occurring over an extensive area of South America, many of them in Brazil. The conifers are represented mainly by allochthonous fossil wood (leaf organs are less frequent) in western Gondwanaland, especially in the Paraná Basin (Irati Formation). Numerous fossil wood genera and species have been described from these Permian strata. These woody plants lived at a time when the global climate was becoming more arid and the Irati Gulf was still isolated from the Panthalassa Sea (Milani et al. 2007).

Fossil wood from the Paraná basin (Irati Formation) was first reported in 1944, found in the municipality of Rio Claro, state of São Paulo, southern Brazil (Maniero 1944). It was originally denominated Dadoxylon whitei, although it was later transferred to a new genus, Polysolenoxylon (Kräusel and Dolianiti 1958). Other samples from the same location led to 
the description of two other genera, Protopodocarpitys (Maniero 1951) and Parataxopitys (Mussa 1974), while discoveries in the state of Rio Grande do Sul (southern Brazil) led to the description of two more species of Polysolenoxylon (Guerra 1975).Two more genera were also found in the state of São Paulo: Brasilestiloxylon and Solenobrasilioxylon (Mussa 1978).

Mussa (1982) was responsible for one of the major contributions to the growing body of knowledge of Gondwanan lignophytes with her unpublished $\mathrm{PhD}$ thesis, a small atlas of fossil wood from the Irati Formation. In this atlas, she described three more species of Polysolenoxylon, a new species of Taxopitys, a new species of Protopodocarpitys, two new species of Brasiloestiloxylon, a new species of Taenopitys, a new species of Kaokoxylon, a new species of Kraeuselpitys and two new species of Solenopitys, as well as seven new genera: Atlanticoxylon (five species), Petalopitys (two species), Paranaseptoxylon (two species), Torosoxylon (two species), Paulistoxylon (one species), Austroscleromedulloxylon (one species) and Antarticoxylon (one species). Many of these taxa are not valid according to the International Code of Nomenclature for Algae, Fungi and Plants (McNeill et al. 2012) because they were not published in an effective publication (Art. 30.8). Some attempts to validate those taxa were made by Merlotti (2009) and Merlotti and Kurzawe (2011), whereas a few problems still remain unsolved.

The Irati Formation is unique in relation to the presence of a great diversity of fossil wood, as well as revealing a large number of specimens with lacunose pith and/or secretory canals, characteristics that are probably xeromorphic (Mussa 1982). Here, three new specimens related to the Coniferales, collected in strata of the Irati Formation, at two locations in the state of São Paulo, are described. The main objective of this paper is the systematic analysis of these specimens, as well as the interpretation of the environmental adaptations resulting from the conditions of deposition of the Irati Formation.

\section{Geologic setting}

The Paraná Basin is a vast intracratonic basin of sediments accumulated from the Silurian to the Cretaceous. It extends for some 1,750,000 $\mathrm{km}^{2}$ throughout southern Brazil, eastern Paraguay, northeastern Argentina and northern Uruguay. In this basin, Milani et al. (1998) recognised six supersequences. The Gondwana I Supersequence corresponds to a complete transgressive-regressive cycle, and consists of three groups, starting with the Itararé Group (Pennsylvanian glacial deposits), the Cissuralian Guatá Group (transgressive coastal and marine deposits, including discrete coal beds) and the Passa Dois Group, in which the fossils described here were found. Deposition of Passa Dois Group lasted from the Cissuralian to the Lopingian (Santos et al. 2006; Ferreira-Oliveira and Rohn 2010; Holz et al. 2010, Guerra-Sommer et al. 2014) or to the Early Triassic (Milani et al. 2007), a regressive period when the Paraná Basin apparently maintained a relatively limited connection to the Panthalassa Sea. The Passa Dois Group consists of four formations, the oldest of which is the Irati Formation (late Artinskian, Santos et al. 2006).

This 35-45 m thick formation is divided into two members, the Taquaral and the Assistência. The latter is mainly characterised by rhythmites of alternating decimetre-thick dolomitic limestones and bituminous shales, as well as more rare facies of thin siltstones, cherts and a basal carbonatic breccia containing evaporites (Milani et al. 2007). The rhythmites probably reflect drier and more humid intervals interspersed in long periods of climatic stability (Amaral, 1971; Hachiro et al. 1993; Rohn et al. 2015; Calça et al. 2016). The main fossils found in the Assistência Member include acritarchs (Neregato et al. 2008), the world famous mesossaurs, pygocephalomorph crustaceans, some huge stromatolites (Ricardi-Branco et al. 2009) and the allochthonous wood, preserved mainly in dolomitic layers. Almost all of the known fossils were collected in quarries, where the upper half of the Assistência Member is often exposed.

\section{Materials and methods}

The specimens were collected at two different locations in the state of São Paulo, both from strata of the Irati Formation (Fig. 1). Sample VE/101 was collected in the "PH7 Quarry", in the municipality of Santa Rosa de Viterbo (coordinates Lat. $21^{\circ} 28^{\prime} 21^{\prime \prime} \mathrm{S} /$ Long. $47^{\circ} 21^{\prime} 46^{\prime \prime} \mathrm{W}$ ), in association with a large concentration of mesosaurid bones, deposited between gigantic stromatolites, in a layer intercalated with the rhythmites (Ricardi-Branco et al. 2009). It is stored in the Paleontological Collection of the Federal University of São Carlos, São Carlos, Brazil. The other two specimens (CP1/ 264 and CP1/265) were collected in the district of Assistência, in the municipality of Rio Claro (coordinates Lat. $22^{\circ} 24^{\prime} 39^{\prime \prime} \mathrm{S} /$ Long. $47^{\circ} 33^{\prime} 39^{\prime \prime} \mathrm{W}$ ), associated with the dolomitic layers of the rhythmites of the upper portion of the Assistência Member; both of these are deposited in the Paleontological Collection of the State University of Campinas, Campinas, Brazil.

The fossils were sectioned and polished along the three usual planes (longitudinal, both radial and tangential, and cross-sectional) and analysed using a stereomicroscope. Scaning Electron Microscope (SEM) images were also obtained from small radial fragments (approximately $5 \mathrm{~cm}^{2}$ ). Measurements were made using AxioVision Zeiss Rel. 4.8 Software. In general, thirty measurements for each dimension were taken. The aspects described and the terminology used follow the proposal of Hartig (1848), Greguss (1955), 
Fig. 1 Map showing the location of the municipalities where the fossils were collected. The excavation in quarries has exposed the upper part of the Irati Formation in outcrops of the Teresina and Corumbataí formations (modified from CPRM 2004 and Cortez et al. 2012)

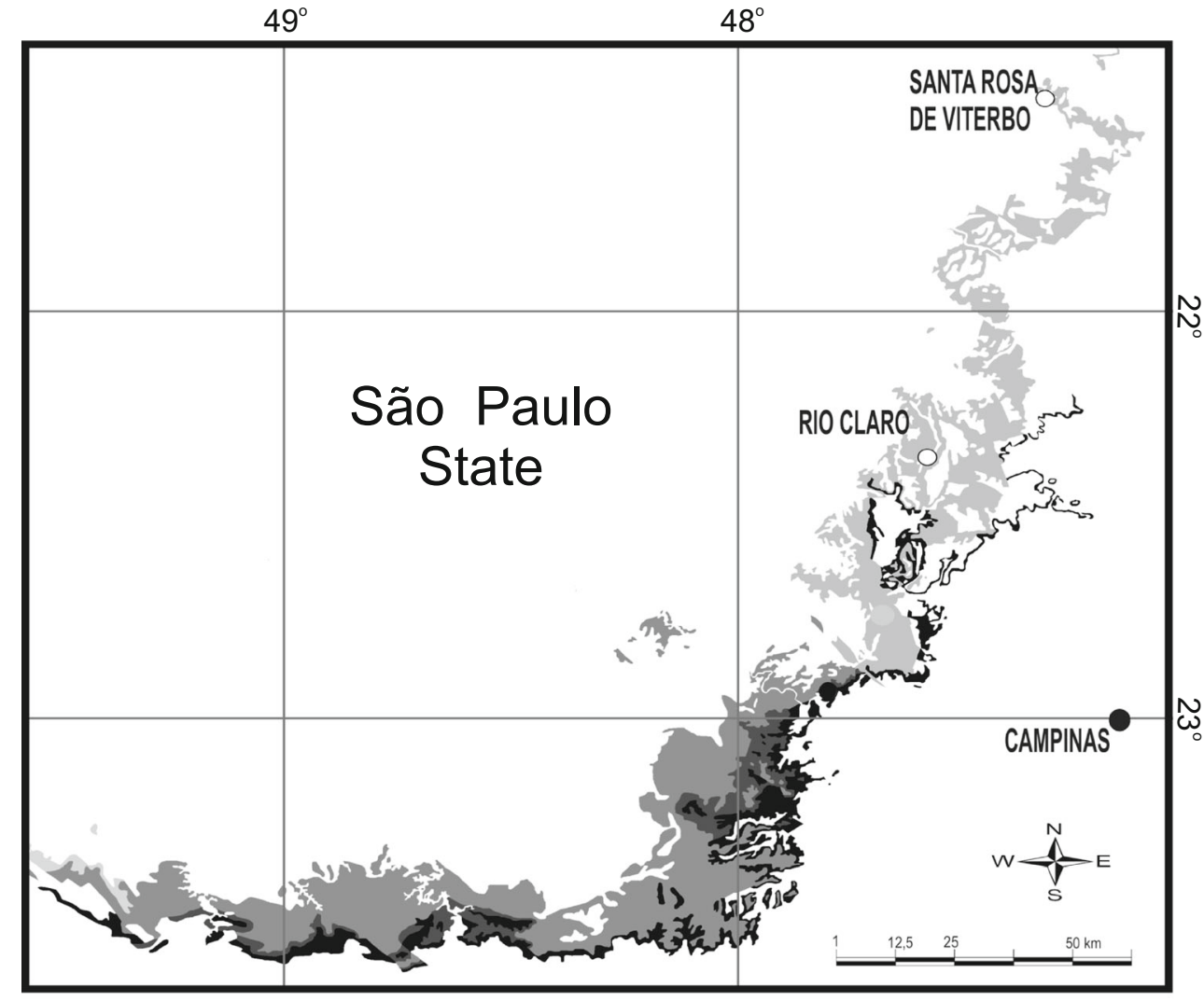

PASSA DOIS GROUP

RIO DO RASTO FORMATION TERESINAFORMATION SERRAALTA FORMATION IRATI FORMATION

O MUNICIPALITIES WHERE THE FOSSILS WERE COLLECTED

- MUNICIPALITIES

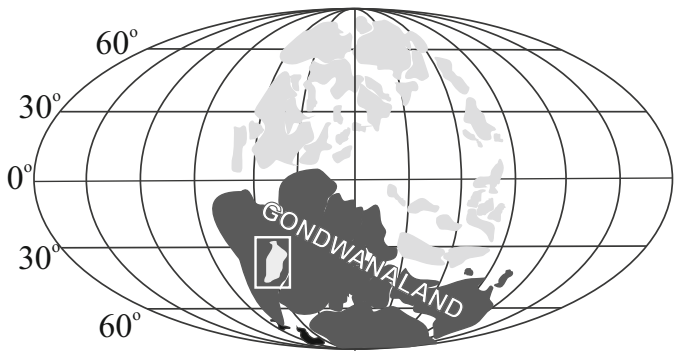

Marguerier (1973), Gifford and Foster (1989), Stewart and Rothwell (1993), Kenrick and Crane (1997) and the International Association of Wood Anatomists Committee (Richter et al. 2004).

\section{Systematic palaeontology}

Tracheophyta Sinnott ex Cavalier-Smith 1998

Euphyllophytina Kenrick et Crane 1997
Coniferales Coniferales Hartig 1848

Solenopitys Kräusel et Dolianiti 1958

Type-species: Solenopitys paulistana Kräusel et Dolianiti 1958

Solenopitys paulistana Kräusel et Dolianiti 1958

Referred specimen: VE/101, Collection of the Federal University of São Carlos, São Carlos, Brazil. 
Locality and age: "PH7" Quarry, municipality of Santa Rosa de Viterbo, state of São Paulo, Brazil. Irati Formation, Assistência Member (Artinskian).

Description: The sample consists of a silicified specimen, approximately $13-16 \mathrm{~cm}$ long and 3-4 cm wide (Fig. 2a, b). Although the cortex is not present, the pith and both primary and secondary xylem are preserved (Fig. 3a). The large rounded pith (approximately $2 \mathrm{~cm}$ in diameter) is heterocelular and solid. Around the periphery, secretory canals are observed, varying in size and shape, with some more radially elongated, while others are tangentially longer (Fig. 3b, c). Their radial diameter is $709 \mu \mathrm{m}(350-1540 \mu \mathrm{m})$, with an average tangential diameter of $681 \mu \mathrm{m}(470-1120 \mu \mathrm{m})$. Some of the canals are closely associated in pairs or triplets. Around the canals there seems to be an epithelium of thin-walled, elongated cells, with an average length of $127 \mu \mathrm{m}(90-160 \mu \mathrm{m})$ and a width of $37 \mu \mathrm{m}(30-50 \mu \mathrm{m})$. Only the periphery of the pith is preserved, and both parenchyma cells and sclereids are visible. The latter are thick-walled, generally polygonal and slightly elongated, often associated with the secretory ducts. These sclereids also vary in size, with an average length of about $212 \mu \mathrm{m}(110-330 \mu \mathrm{m})$ and a width of $131 \mu \mathrm{m}(90$ $190 \mu \mathrm{m})$. The protoxylem is of the mesarch type (Fig. 3d), with tracheids having an average radial diameter of $37 \mu \mathrm{m}$ $(20-40 \mu \mathrm{m})$ and a tangential diameter of $29 \mu \mathrm{m}(20-$ $40 \mu \mathrm{m})$. The metaxylem tracheids have an average radial diameter of $59 \mu \mathrm{m}(50-80 \mu \mathrm{m})$, with a tangential diameter of $47 \mu \mathrm{m}(30-60 \mu \mathrm{m})$.

The decorticated wood reveals three true growth rings, as well as several false rings (Fig. 3e). In cross section, the early wood tracheids are mostly polygonal (hexagonal) with radial and tangential diameters of $49 \mu \mathrm{m}(40-70 \mu \mathrm{m})$ and $50 \mu \mathrm{m}$ (40-70 $\mu \mathrm{m})$, respectively (Fig. 3f) Late wood tracheids are more rectangular, with a decreased radial diameter is $23 \mu \mathrm{m}$ $(20-40 \mu \mathrm{m})$, while the tangential diameter is $46 \mu \mathrm{m}(30-$ $50 \mu \mathrm{m})$. Transition from early wood to late wood is gradual (Fig. 3g). Vascular rays are uniseriate and homocelular, ranging from $2-12$ cells in height $(57-357 \mu \mathrm{m})$, usually separated by $2-9$ rows of tracheids. Vascular ray cells have a length of $81 \mu \mathrm{m}(65-94 \mu \mathrm{m})$ and a width of $31 \mu \mathrm{m}(27-37 \mu \mathrm{m})$.

Radial pits vary from separate to contiguous; almost all are uniseriate (Fig. 4a, b). The few multiseriate pits are sub-opposite (Fig. 4c). Diameter of the radial pits is a $11 \mu \mathrm{m}$ (6-17 $\mu \mathrm{m})$. Cross-fields, although poorly preserved, appear to have oculipores which are contiguous and alternate. Most of the cross-fields have two pits, although three and four pits are also observed. Vertical diameter of the oculipores is $14 \mu \mathrm{m}$ (11-19 $\mu \mathrm{m})$, while the width is $13 \mu \mathrm{m}(9-14 \mu \mathrm{m})$.

Remarks: The presence of a peripheral secretory system associated with a solid, heterocellular pith is a diagnostic feature of the genus Solenopitys (Kräusel and Dolianiti 1958), described in strata of the Irati Formation (Fig. 3a, b). It clearly differs from the two species of Solenopitys described by
Fig. 2 General view of the taxa described. a Solenopitys paulistana, associated with mesosaurid bones (VE/101). Scale bar $=3 \mathrm{~cm}$. b Solenopitys paulistana, associated with mesosaurid bones. Scale bar $=$ $2 \mathrm{~cm}$. c Abietopitys sp. (CP1/264). Scale bar $=2 \mathrm{~cm}$. d Abietopitys $\mathrm{sp}$. (CP1/264). Scale bar $=3 \mathrm{~cm}$. e Atlanticoxylon ibiratinum sp. nov. (CP1/ 265). Scale bar $=3 \mathrm{~cm}$. f Atlanticoxylon ibiratinum sp. nov. (CP1/265). Scale bar $=4 \mathrm{~cm}$

Mussa (1986), also from specimens collected in the Irati Formation: Solenopitys rusticana and Solenopitys picturata. In $S$. rusticana the pith is slightly winding, but in the specimen described here doesn't have the same structure in front of each canal. It differs from $S$. picturata, which has sclerenchyma cells typically located only in the central portion of the pith, because although the central portion of the pith is not preserved here, we can observe sclereids in the periphery. Consequently, we infer that in the studied specimen the sclereids are scattered throughout the pith and it has thus been tentatively assigned to the Solenopitys paulistana.

In fossil wood systematics, genera are established largely on the basis of secondary xylem characteristics, especially for tracheidoxyls, since no primary characteristics are available. Once the pith and primary xylem of the studied sample is preserved, the classification based on the consideration of primary xylem characteristics, but the type of associated tracheidoxyls has also been analysed. If only secondary xylem were considered, the sample would be characterised by mixed radial pitting (no more than $90 \%$ and not less than $10 \%$ of contiguous pits; senu Philippe and Bamford 2008), with araucarioid cross-fields containing contiguous oculipores (Philippe 2011). The combination of mixed radial pitting with araucarioid cross-fields would suggest a classification in the genus Brachyoxylon (Bamford and Philippe 2001). The specimen has thus been identified as Solenopitys paulistana, although the secondary xylem is of the Brachyoxylon type.

\section{Atlanticoxylon Mussa 1986}

Type-species: Atlanticoxylon salpicatum Mussa 1986 Atlanticoxylon ibiratinum n. sp.

Etymology: From ibiratan in Tupi Guarani, which means hard wood (ibira $=$ wood and $\tan =$ hard).

Referred specimen: CP1-265, Paleontology Collection of the University of Campinas, Campinas, Brazil.

Locality and age: District of Assistência, municipality of Rio Claro, state of São Paulo, Brazil. Assistência Member, Irati Formation (Late Artinskian).

Diagnosis: Lobed, lacunose pith, with randomly arranged lacunae; contains "nests" of sclereids; large central canal, with smaller canals forming a peripheral system and also scattered throughout the pith; endarch protoxylem extending into the pith.

Description: The sample is a silicified small stem, 19-21 cm long and 6-8 cm wide. It corresponds to a decorticated 


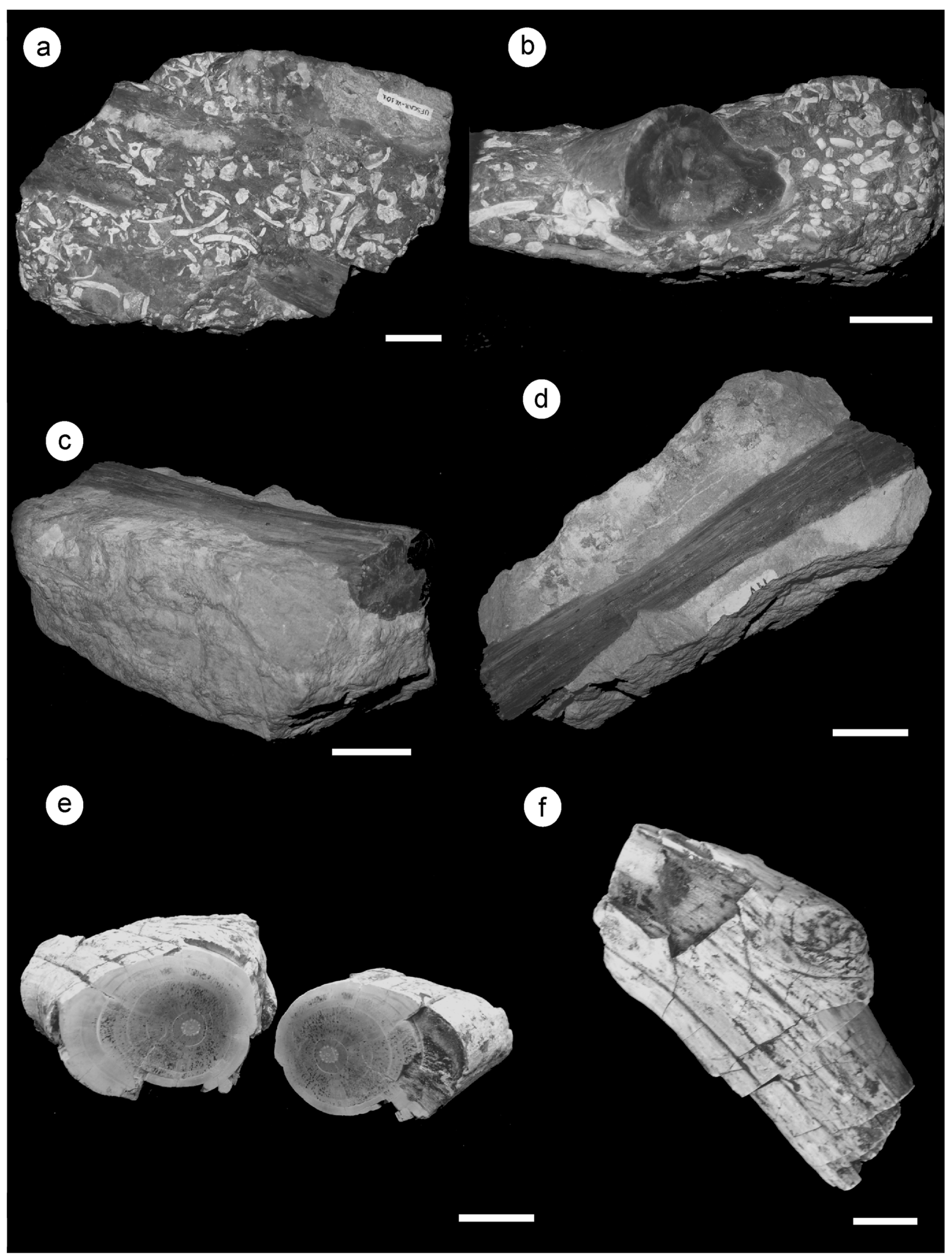


specimen, which has four nodes (Fig. 2e, f). Pith, as well as both primary and secondary xylem, is preserved. Pith varies from $6-8 \mathrm{~mm}$ in diameter; it is lobed, heterocelular and lacunose, with randomly arranged lacunae (Fig. 5a, b). There are peripheral secretory canals in the lobes, as well as smaller internal canals; the large central canal is about $1-2 \mathrm{~mm}$ in diameter (Fig. 5c). Epithelium of the secretory system is composed of thin-walled elongated cells, also present throughout the pith, delimiting the lacunae. In addition to the parenchyma cells, there are "nests" of sclereids, which are scattered among many canals. Sclereids are usually rounded and thick-walled (Fig. 5d), with an average diameter of 62$83 \mu \mathrm{m}(40-110 \mu \mathrm{m})$. Primary xylem forms wedges that are interspersed with the lobes of the pith (Fig. 5e). Protoxylem is of the endarch type. Protoxylem tracheids have diameter of $25 \mu \mathrm{m}(20-30 \mu \mathrm{m})$ and a tangential diameter of $20 \mu \mathrm{m}(10$ $30 \mu \mathrm{m})$. Metaxylem tracheids have an radial diameter of $43 \mu \mathrm{m}(30-50 \mu \mathrm{m})$ and a tangential diameter of $28 \mu \mathrm{m}(20-$ $40 \mu \mathrm{m})$.

Secondary xylem shows true growth rings, with nine being visible; false rings are also common (Fig. 5f). In cross section, the earlywood tracheids are mostly polygonal (hexagonal), with two sub-radial walls usually being visible; the radial diameter is $37 \mu \mathrm{m}(30-50 \mu \mathrm{m})$ and the tangential diameter is $33 \mu \mathrm{m}(20-40 \mu \mathrm{m})$. Late wood tracheids tend to decrease in radial diameter, averaging $16 \mu \mathrm{m}(10-20 \mu \mathrm{m})$, while the tangential diameter averages $30 \mu \mathrm{m}(20-40 \mu \mathrm{m})$. The transition from earlywood to late wood is gradual. Vascular rays are uniseriate (rarely biseriate), ranging from $4-5$ cells in height (about $100-130 \mu \mathrm{m}$ ), generally separated by $3-5$ rows of tracheids. Vascular ray cells have a length of $133 \mu \mathrm{m}(10$ $162 \mu \mathrm{m})$ and a width of $27 \mu \mathrm{m}(20-30 \mathrm{~mm})$.

The majority of the radial pits are uniseriate (Fig. 6a-d), varying from separate to contiguous. The few biseriate pits are mostly alternate. These pits have a diameter of $13 \mu \mathrm{m}(8-$ $17 \mu \mathrm{m})$, and a width of $14 \mu \mathrm{m}(11-17 \mu \mathrm{m})$. Cross-fields contain contiguous oculipores (Fig. 6e, f), with an average length of $11 \mu \mathrm{m}(8-15 \mu \mathrm{m})$ and an average width of $9 \mu \mathrm{m}(6-$ $11 \mu \mathrm{m})$; there are commonly two to four pits per field.

Remarks: Among the fossil woods of Gondwanaland characterised by pith with secretory ducts, the most common genera are Polysolenoxylon (Kräusel et Dolianiti, 1958) and Barakaroxylon (Kulkarni, Maithy et Surange, 1971). However, their treatment tends to be confusing. Poly-solenoxylon, according to the original description, corresponds to woods with a lacunose pith and a system of peripheral canals, accompanied by a few scattered canals in the more central region, but with no main central canal. Barakaroxylon, on the other hand, was initially described as having a solid pith (Kulkarni et al. 1971), thus contrasting with Polysolenoxylon. Subsequent studies, however, have revealed that the specimens originally identified as Barakaroxylon actually had a partially lacunose pith (Mussa 1986), as well as a main central
Fig. 3 Solenopitys paulistana (VE/101). a Cross-section showing the large pith with peripheral secretory canals. Scale bar $=1000 \mu \mathrm{m}$. b Detail of a secretory canal showing surrounding sclereids. Scale bar = $200 \mu \mathrm{m}$. c Split secretory canal. Scale bar $=200 \mu \mathrm{m}$. d Primary xylem with mesarchic protoxylem. Scale bar $=200 \mu \mathrm{m}$. e Secondary wood with true growth rings. Scale bar $=500 \mu \mathrm{m}$. $\mathbf{f}$ Detail of a growth ring showing the late wood and the early wood. Scale bar $=250 \mu \mathrm{m}$. $\mathrm{g}$ Detail of a growth ring showing the late wood and the early wood. Scale bar= $100 \mu \mathrm{m}$. Key: c secretory canal, ew early wood, lw late wood, mxyl metaxylem, pxyl protoxylem, scl sclereid, sxyl secondary xylem

canal and a peripheral system of canals, with the two systems occasionally linked by connecting branches.

Moreover, Mussa (1986) found that some of the specimens initially identified as Polysolenoxylon by Kräusel and Dolianiti (1958) did not fit their diagnosis, because these did have a central canal. She thus created a new genus, Atlanticoxylon, to accommodate specimens of wood with a main central canal as well as peripheral canals, but without the connecting branches, as in Barakaroxylon.

When describing the genus Atlanticoxylon, Mussa (1982, 1986) created seven new species: Atlanticoxylon salpicatum; Atlanticoxylon marginatum; A. foraminatum; A. scallonatum; A. porangabense; A. monocanalosum (Kulkarni) Mussa and A. kraeuselii (Maheshwari) Mussa. The first five were from the Paraná Basin (Irati Formation), whereas the latter two represent new combinations of Indian species.

The wood described here must be considered to be a new taxon. It differs from A. salpicatum, A. marginatum and A. foraminatum, mainly because in these species the lacunae tend to be distributed radially (Fig. 5a) and not randomly arranged as in here. Moreover, there is no evidence of peripheral secretory canals in those species. It also differs from A. scallonatum, since there is no mention of secretory canals other than those in the centre. The wood studied here seems to be more close to the description of Atlanticoxylon porangabense. Both have central and peripheral canals, but the sclereids of $A$. porangabense are not organised into nests, they are rather scattered throughout the pith. This makes it impossible to identify our specimen as any of the species of Atlanticoxylon found in the Paraná Basin, and the new taxon Atlanticoxylon ibiratanum has been proposed. No comparison with the Indian species was made, as the affinity of the combinations presented by Mussa (1986) is not very clear.

There is a species described as Polysolenoxylon bortoluzzii by Guerra (1975), which seems quite similar to the wood under analysis here. Polysolenoxylon bortoluzzii also has a heterocellular lacunose pith, with a main central canal and a system of peripheral canals. However, as Merlotti (2009) points out, there is no sign of the main characteristics of the genus of Polysolenoxylon described by Mussa in 1986: a system of canals dispersed in the pith. In the publication originally describing $P$. bortoluzzi, only a sketch of the pith is presented (Guerra 1975, plate 4, fig. C) and no microphotographs of a 

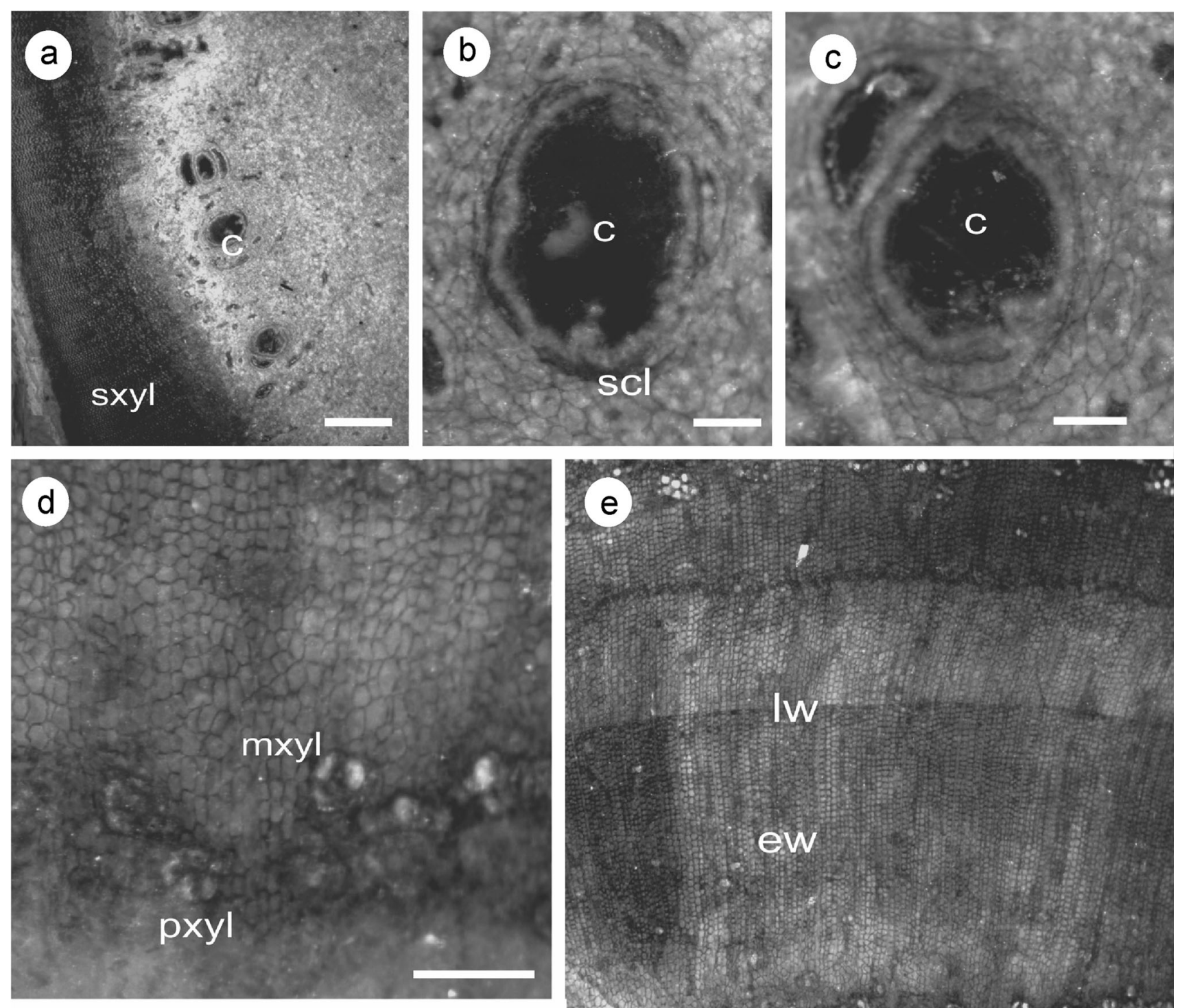

e

.
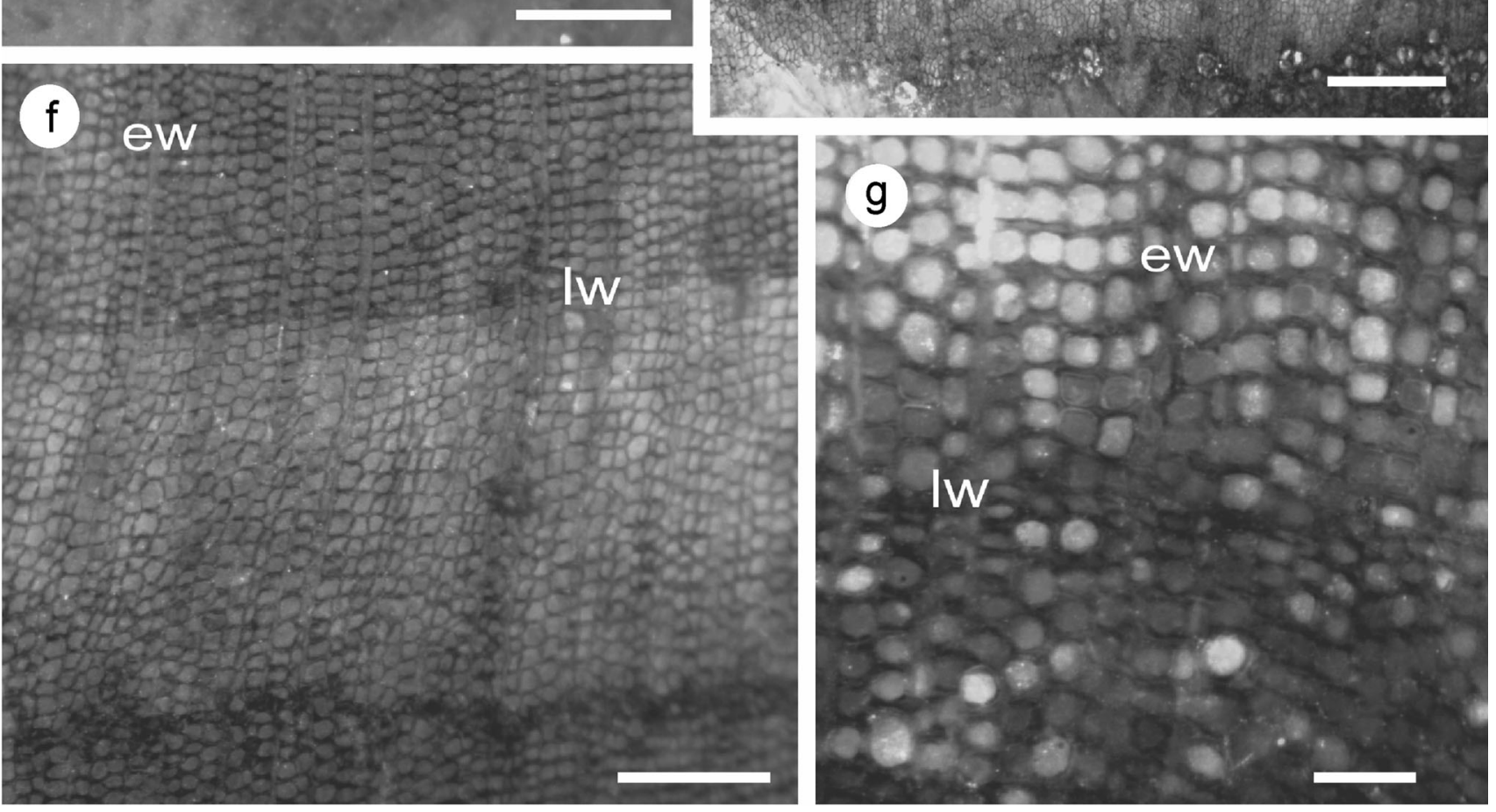

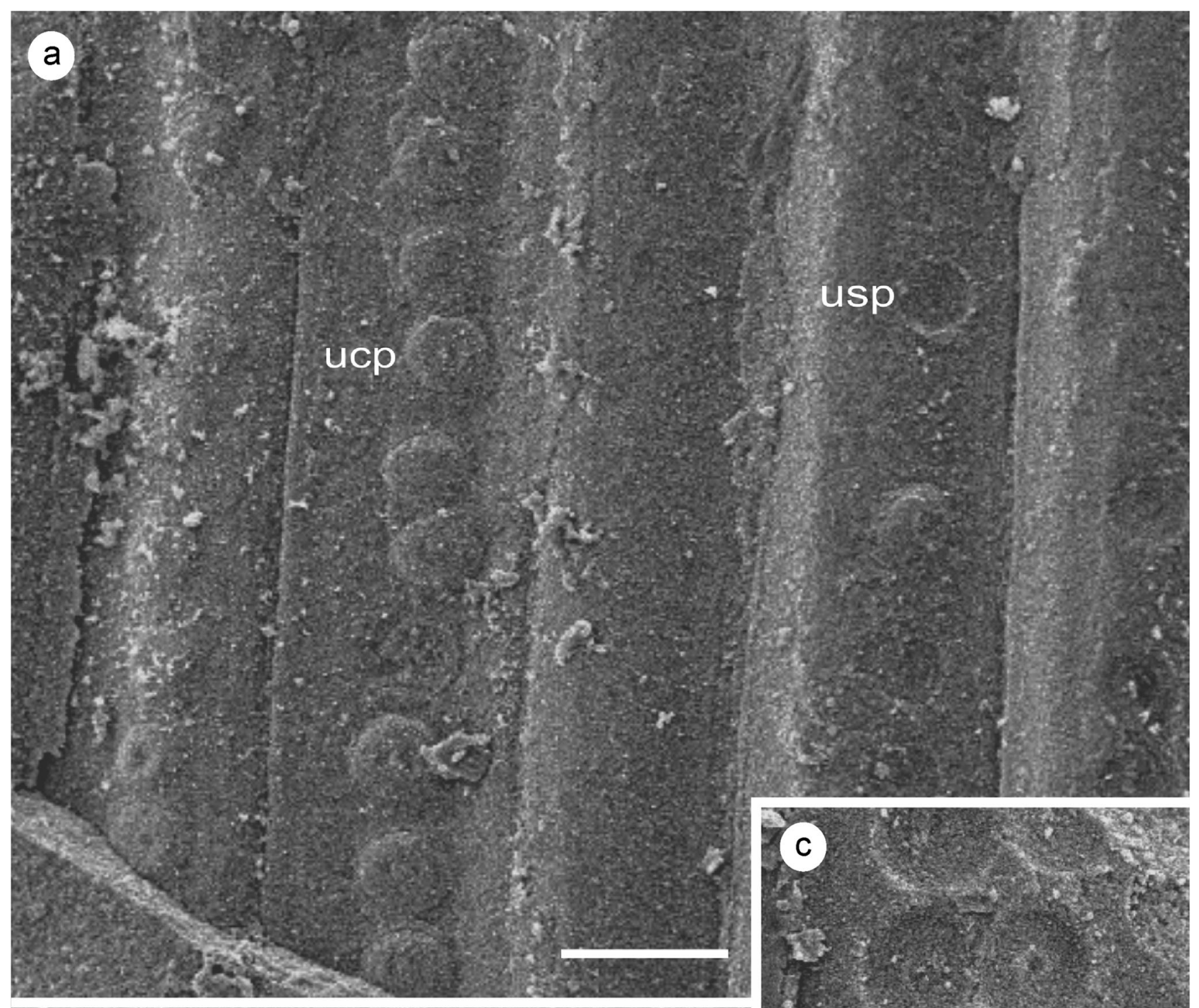

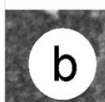

b

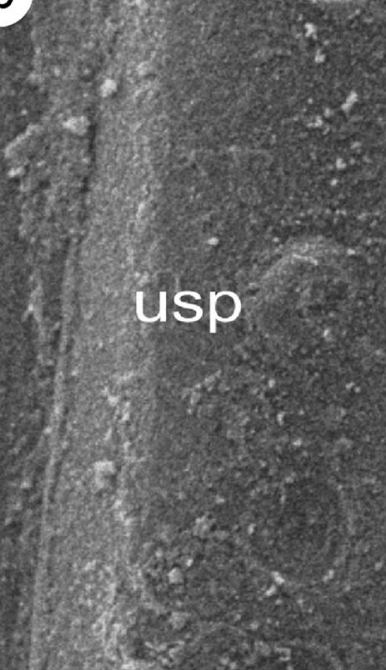

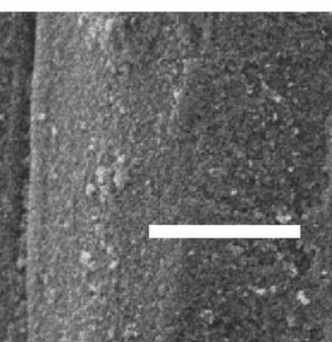

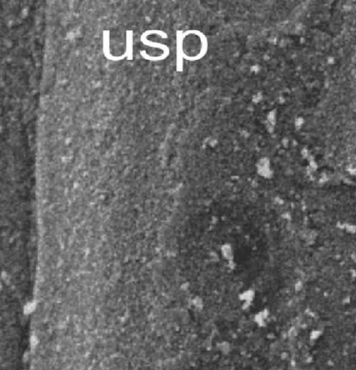

Fig. 4 Solenopitys paulistana (VE/101) anatomical details at SEM. a Longitudinal radial section showing uniseriate bordered pits, which may be contiguous or separate. Scale bar $=20 \mu \mathrm{m}$. b Uniseriate
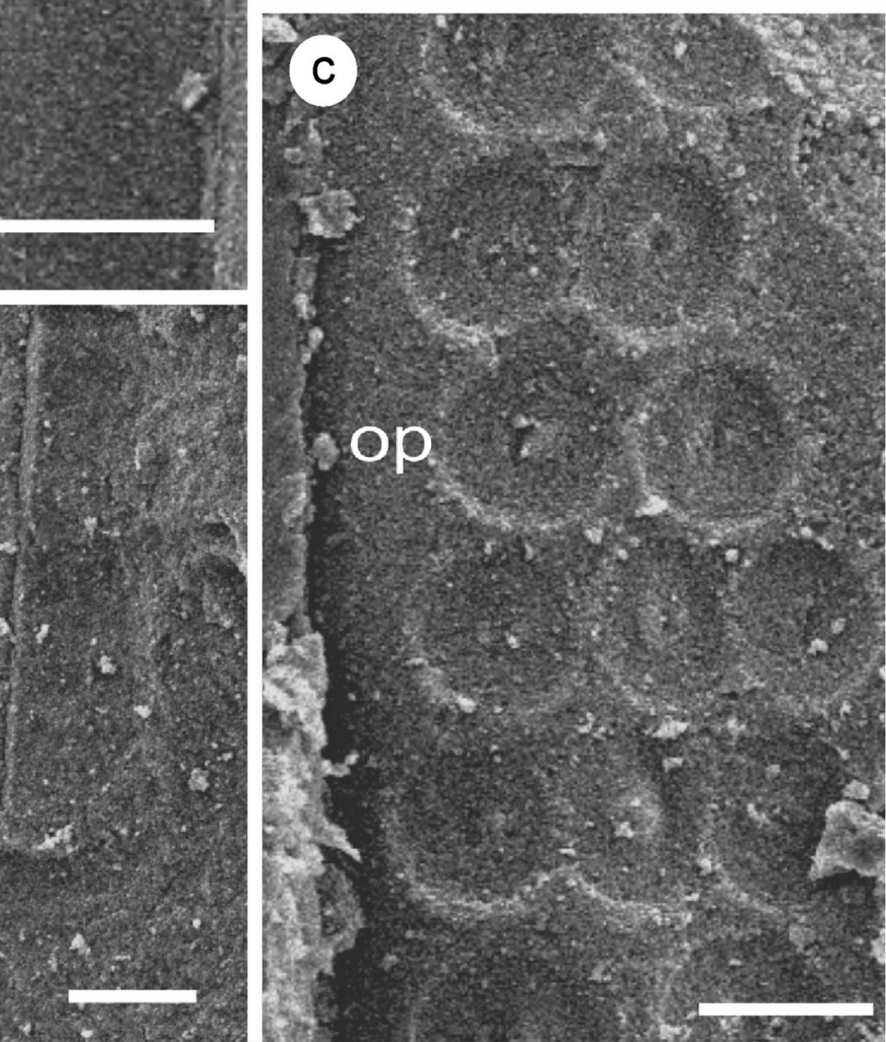

contiguous pits. Scale bar $=10 \mu \mathrm{m}$. c Multisseriate opposed pits. Scale bar $=10 \mu \mathrm{m}$. Key: op opposed pits, ucp uniseriate contiguous pits, usp uniseriate non-contiguous pits 

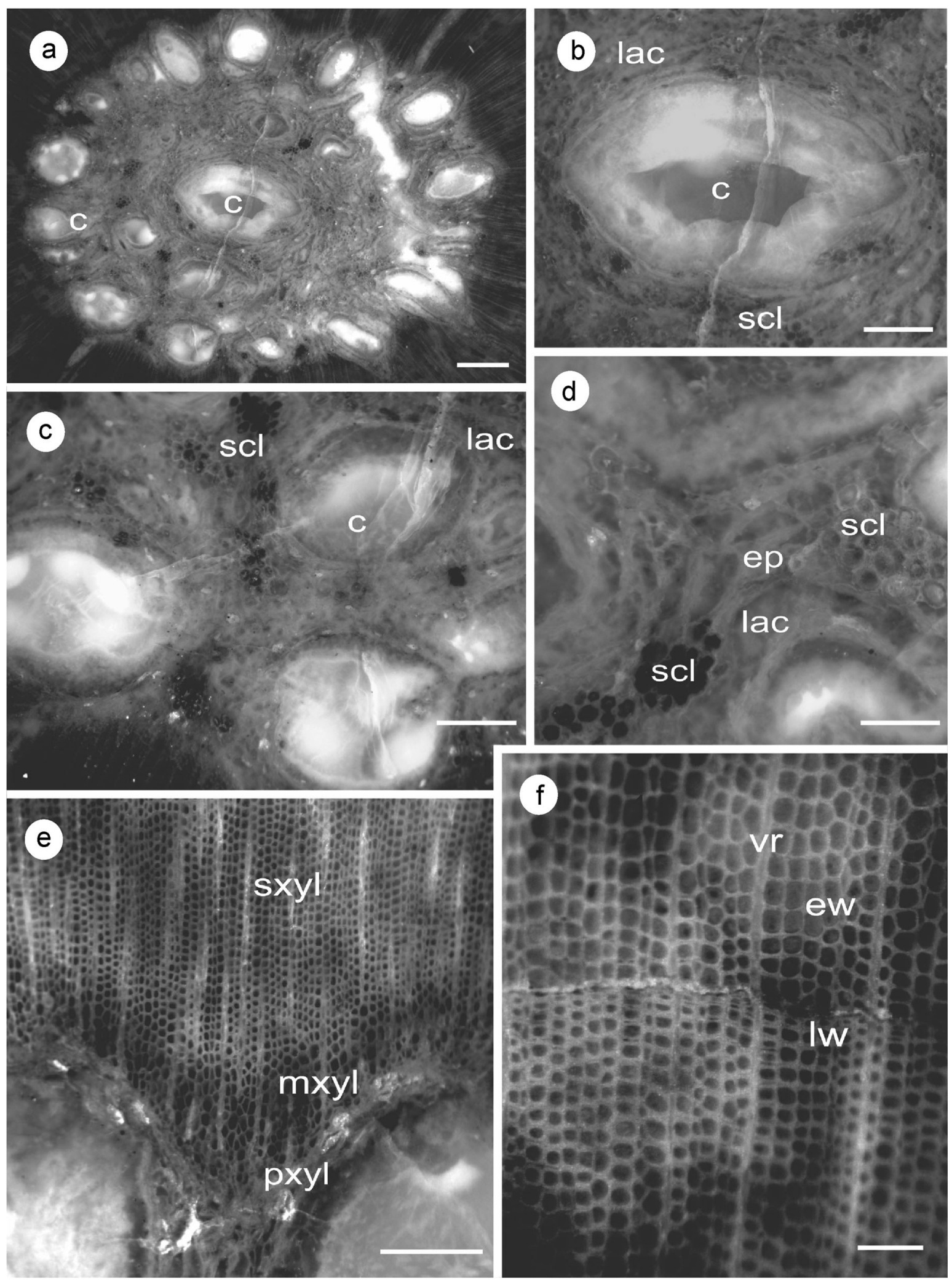

Fig. 5 Atlanticoxylon ibiratinum sp. nov (CP1/265). a Cross-section showing heterocellular lacunose pith with a main central secretory canal, a peripheral secretory system and scattered interior canals. Scale bar = $1000 \mu \mathrm{m}$. b Detail showing the central canal, some lacunae and some sclereids. Scale bar $=500 \mu \mathrm{m}$. $\mathrm{c}$ Detail showing two peripheral canals and an interior canal. Scale bar $=400 \mu \mathrm{m}$. d Sclereids and parenchyma cells.
Scale bar $=250 \mu \mathrm{m}$. e Primary xylem wedge between two pith lobes; endarchic protoxylem. Scale bar $=250 \mu \mathrm{m}$. f Secondary xylem with true growth rings. Scale bar $=100 \mu \mathrm{m}$. Key: ch secretory canal, ew early wood, lac lacunae, lw late wood, mxyl metaxylem, pxyl protoxylem, scl sclereid, sxyl secondary xylem, vr vascular ray 

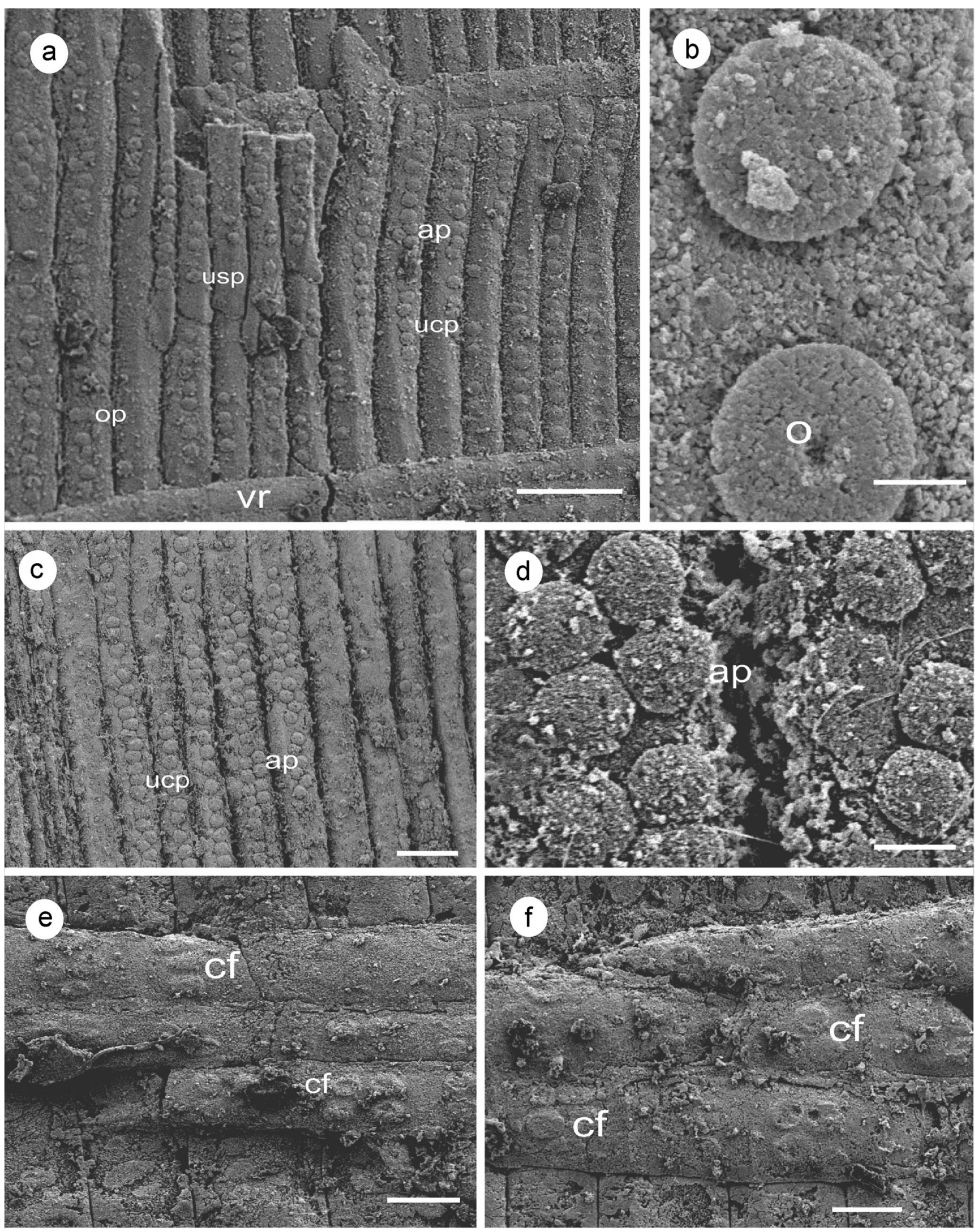
Fig. 6 Atlanticoxylon ibiratinum sp. nov (CP1/265) anatomical details at SEM. a Longitudinal radial section showing the different types of radial pits: uniseriate, bisseriate, contiguous and non-contiguous. Scale bar = $100 \mu \mathrm{m}$. b Detail of non-contiguous pits, which are commonly rounded. Scale bar $=5 \mu \mathrm{m}$. c Area showing portions of tracheids without pits. Scale bar $=50 \mu \mathrm{m}$. d Alternate pits which are commonly hexagonal. Scale bar $=10 \mu \mathrm{m}$. e Cross-fields with contiguous oculipores (arrow). Scale bar $=$ $25 \mu \mathrm{m}$. f Cross-fields with contiguous oculipores (arrow). Scale bar $=$ $20 \mu \mathrm{m}$. Key: ap alternate pits, cf cross-field pits, o pit opening, op opposed pits, ucp uniseriate contiguous pits, usp uniseriate separate pits, vr vascular ray

cross-section of the pith are provided. The re-examination of the specimen by Merlotti (2009) was unable to provide a new combination of characteristics due to the precarious preservation of the specimen. This lack of a figure showing the essential characteristics of the species corroborated by an analysis of the type specimen of $P$. bortoluzzi meant that it could not be used for identification purposes, as outlined in the International Code of Nomenclature for Algae, Fungi and Plants (McNeill et al. 2012). Since it is an invalid taxon, even though the description provided seems to describe a similar species, it was ignored.

As proposed above, the secondary characteristics were also compared. This secondary xylem presents mixed radial pittings, as well as cross-fields of the araucarioid type (contiguous oculipores, Fig. 6e). As discussed above, this combination indicates a correspondence with tracheidoxyls classified as Brachyoxylon (sensu Bamford and Philippe 2001; Philippe and Bamford 2008).

The specimen being studied here was denominated Atlanticoxylon ibiratinum sp. nov.; it presents a secondary xylem of the Brachyoxylon type.

Abietopitys Kräusel, 1928

Type-species: Abietopitys perforata Kräusel, 1928

\section{Abietopitys sp.}

Referred specimen: CP1/264, Paleontology Collection of the University of Campinas, Campinas, Brazil.

Locality and age: District of Assistência, municipality of Rio Claro, state of São Paulo, Brazil. Assistência Member, Irati Formation (Late Artinskian).

Description: The sample studied is a dark silicified specimen, partially immersed in a carbonate rock matrix, which underwent little compression (Fig. 2c, d). It is about $15 \mathrm{~cm}$ long and $2.5 \mathrm{~cm}$ wide. A single branch node is visible on the outer surface. Pith and both primary and secondary xylem have been preserved, but not the cortex. Pith is lobed and solid, about $7 \mathrm{~mm}$ in diameter; it is clearly homocelular and presents parenchyma cells, with no secretory ducts (Fig. 7a, b). Wedges of the primary xylem extending into the pith give it the lobed appearance. The protoxylem is mesarch (Fig. 7c, d), with the tracheids having a radial diameter of $17 \mu \mathrm{m}(10$ $20 \mu \mathrm{m})$ and a tangential diameter of $20 \mu \mathrm{m}(10-30 \mu \mathrm{m})$. Tracheids of the metaxylem have a radial diameter of $35 \mu \mathrm{m}$ $(30-40 \mathrm{~mm})$ and a tangential diameter of about $31 \mu \mathrm{m}(20$ $40 \mu \mathrm{m})$.

Secondary xylem has true growth rings (Fig. 7e), with three being visible in the sample; false rings are also present. Earlywood tracheids (Fig. 7f), in cross section, are polygonal, with a radial diameter of $33 \mu \mathrm{m}(30-40 \mu \mathrm{m})$ and a tangential diameter of $31 \mu \mathrm{m}(20-50 \mu \mathrm{m})$. Late wood tracheids (Fig. 7f) are rectangular in cross section, with a radial diameter of $15 \mu \mathrm{m}(10-20 \mu \mathrm{m})$ and a tangential diameter of $26 \mu \mathrm{m}(20-$ $30 \mu \mathrm{m})$. Vascular rays are homocelular, uniseriate and separated by 2-22 rows of tracheids. They are generally $2-5$ cells high (39-94 $\mu \mathrm{m})$, reaching in rare cases up to 10 cells in height $(250 \mu \mathrm{m})$.

Radial walls have many regions without pitting, where pits do exist, they are mostly uniseriate and contiguous (Fig. 8ad). The radial pits are $11 \mu \mathrm{m}$ high $(7-14 \mu \mathrm{m})$, and $10 \mu \mathrm{m}$ wide (8-12 $\mu \mathrm{m})$. Cross-field pits are poorly preserved (Fig. 8e), but some rare preserved pits seem to be separate oculipores of the cupressoid type (Fig. 8f). In most cases, there are one or two pits per field, occasionally three or four. Pits are rounded and elongated with a length of $7.8 \mu \mathrm{m}(6.7-8.6 \mu \mathrm{m})$ and a width of $5.8 \mu \mathrm{m}(4.6-7.6 \mu \mathrm{m})$.

Remarks: Kräusel (1928) described Abietopitys from specimens that were previously included in Dadoxylon. The main feature of the genus is the presence of abietoid vascular rays (with thick walls and pits). Moreover, the diagnosis of Abietopitys includes a "homocelular pith, without lacunae, and primary xylem located at the edge of wedges which extend into the pith" (Mussa 1982). The specimen examined here shows vascular rays with separate pits (as in the abietoid cross-fields), but these are not well enough preserved to observe the thickness of their walls. The pith is solid and homocelular, with intruding wedges of primary xylem. So, although there is some doubt, the present sample has been tentatively identified as Abietopitys.

An emendation of the genus Abietopitys by Merlotti (2009) includes the possible presence of an endarch protoxylem, in addition to the mesarch type mentioned in the original description (Fig. 9). In this same paper, the author proposes synonymy with the genus Bageopitys. Although we agree with the inclusion of the characteristics of "endarch protoxylem", and with the proposed synonymy, we disagree with the statement that the pith is circular, since the original description points to the existence of wedges of primary xylem penetrating the pith, which leaves it lobed, but not circular. The specimen studied here is not well enough preserved to compare it at the level of a species; in order to avoid an inflation of taxa, it has been classified as Abietopitys sp. 

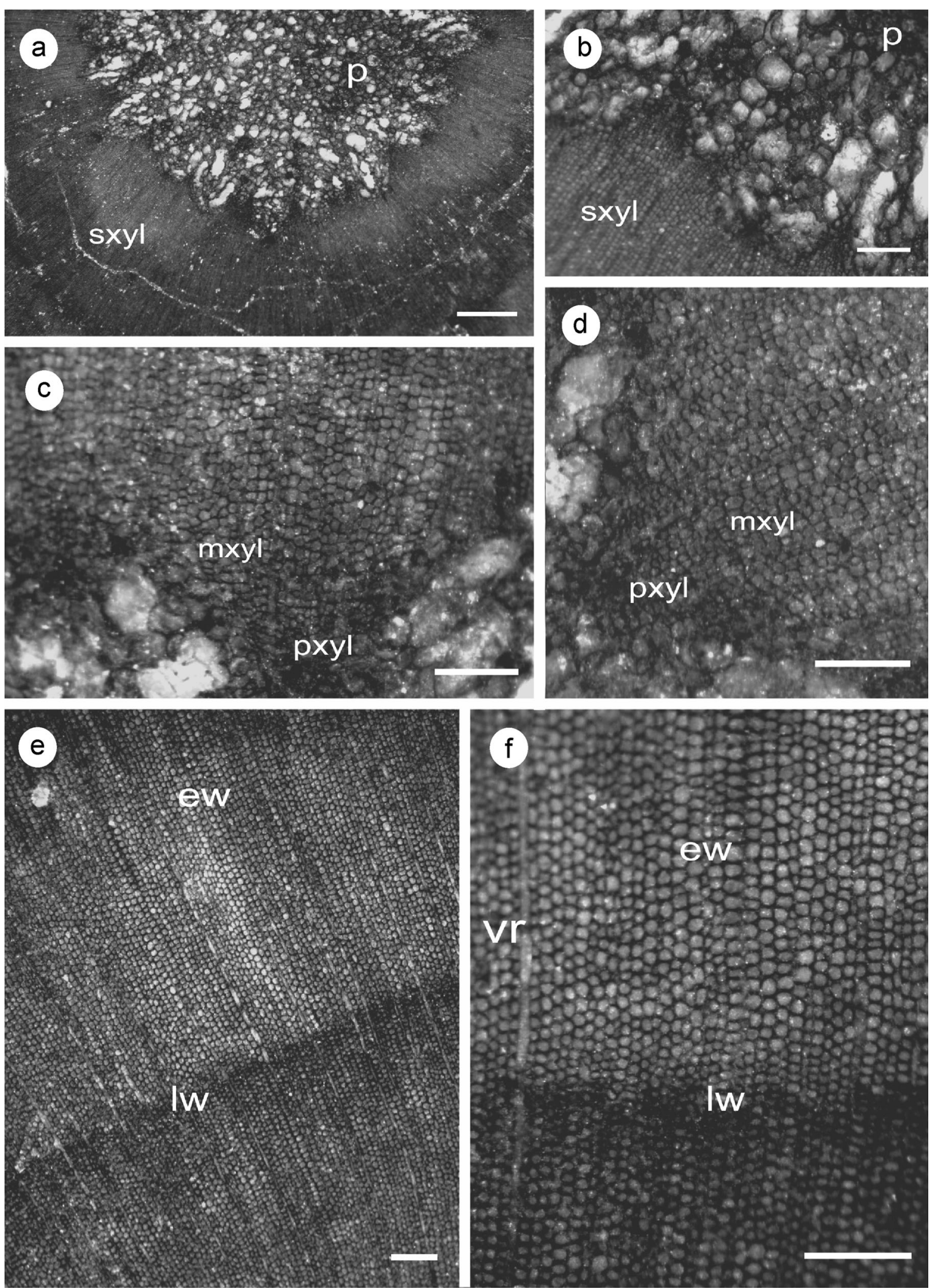

Fig. 7 Abietopitys sp. (CP1/264). a Cross-section showing lobed pith, the edges of primary xylem and a portion of secondary xylem. Scale bar $=1000 \mu \mathrm{m}$. $\mathbf{b}$ Detail of peripheral pith region, showing edges of primary xylem and some parenchyma cells. Scale bar $=250 \mu \mathrm{m}$. c, d Primary xylem with mesarchic protoxylem. Scale bar $=200 \mu \mathrm{m}$. e Secondary wood with true growth rings. Scale bar $=200 \mu \mathrm{m}$. f Detail of a growth ring showing two to three layers of late wood cells and numerous layers of early wood cells. Scale bar $=200 \mu \mathrm{m}$. Key: ew early wood, lw late wood, mxyl metaxylem, p pith, pxyl protoxylem, sxyl secondary xylem, vr vascular ray 

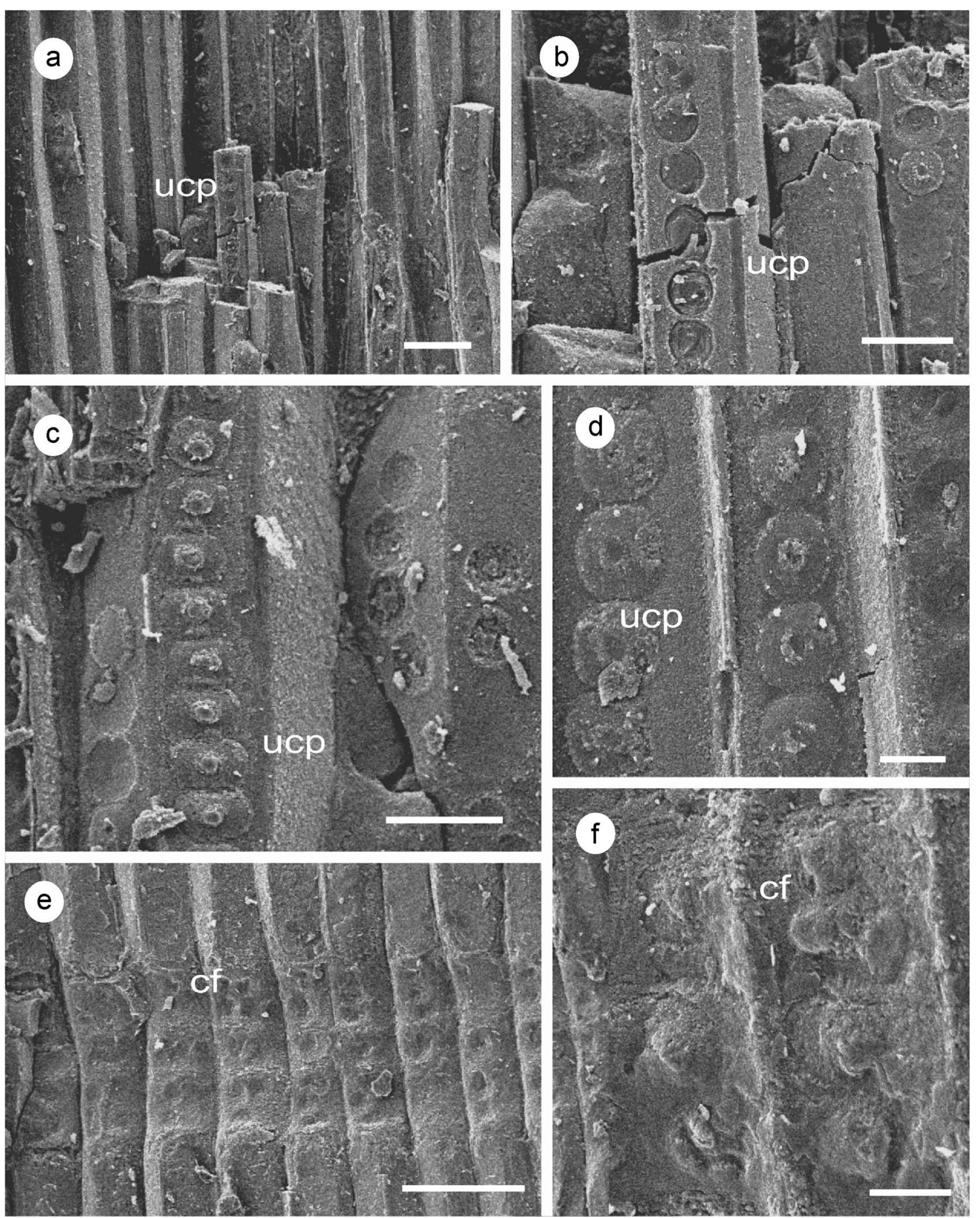

Fig. 8 Abietopitys sp. (CP1/264) anatomical details at SEM. a Longitudinal radial section showing a large portion with no pits, and a region of uniseriate contiguous pits. Scale $b a r=50 \mu \mathrm{m}$. b Longitudinal radial section showing a large portion with no pits, and a region of uniseriate contiguous pits. Scale $b a r=20 \mu \mathrm{m}$. c Region with uniseriate contiguous pits in one of the two sub-radial walls. Scale bar $=20 \mu \mathrm{m}$. d Uniseriate contiguous pits. Scale bar $=10 \mu \mathrm{m}$. e Cross-fields with separate pits. Scale bar $=50 \mu \mathrm{m}$. $\mathbf{f}$ Detail of a cross-field showing the variable number of oculipores (arrow). Scale bar $=10 \mu \mathrm{m}$. Key: cf cross-field pits, ucp uniseriate contiguous pits, vr vascular ray 
(a)

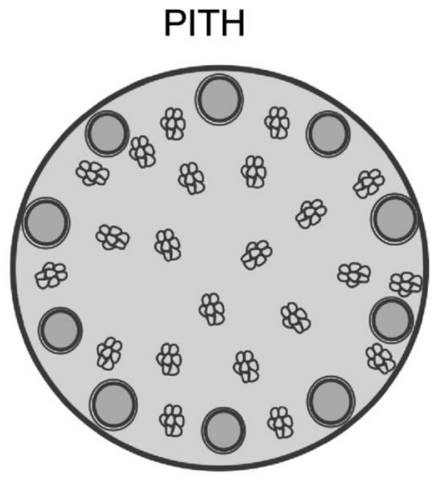

(b)

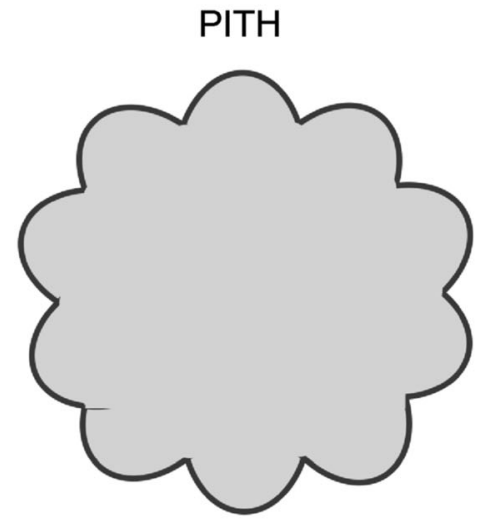

(c)

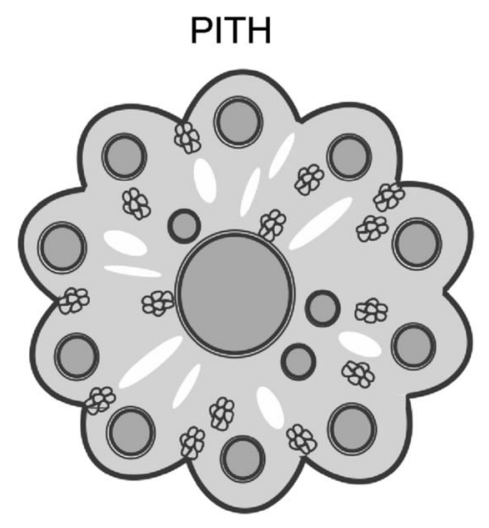

RADIAL WALLS

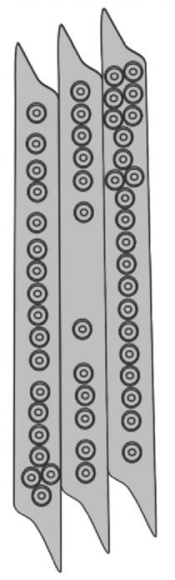

RADIAL WALLS

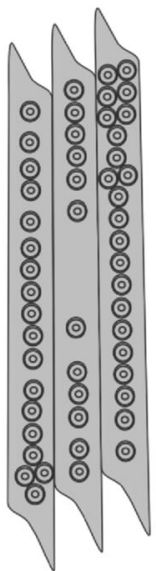

RADIAL WALLS

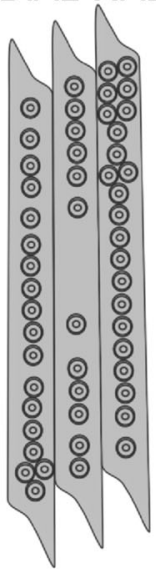

CROSS - FIELDS

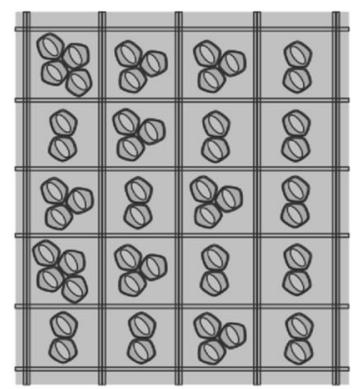

CROSS - FIELDS

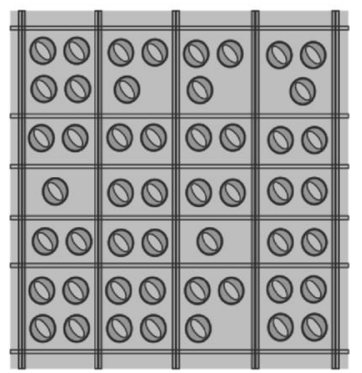

CROSS - FIELDS

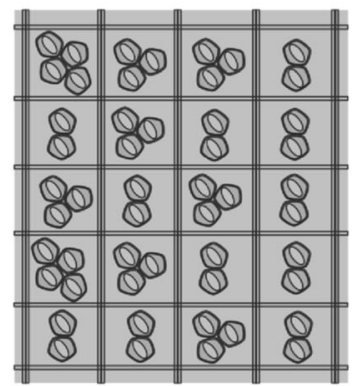

\section{Ocanal SClereids @RADIALPIT C CROSS - FIELD PIT}

Fig. 9 Schematic illustration of the main features of the taxa described. a Solenopitys paulistana, with a solid, heterocellular pith with a peripheral secretory canal system, and with a secondary xylem of the Brachyoxylon type. b Abietopitys sp., with a solid, lobed, homocellular pith and associated to a secondary xylem of the Protobrachyoxylon type. c Atlanticoxylon ibiratinum sp. nov., with a lacunose, heterocellular pith with "nests" of sclereids, with a central secretory canal and a peripheral system of canals and associated to a secondary xylem of the Brachyoxylon type 
In the tracheidoxyl portion, the pattern of radial pitting is interpreted as being of the mixed type. The association of mixed radial pits with the cupressoid cross-fields indicates that the tracheidoxyl portion may be related to Protobrachyoxylon or Brachyoxylon (sensu Bamford and Philippe 2001; Philippe and Bamford 2008). The specimen is identified as Abietopitys sp. and has a secondary xylem of the Protobrachyoxylon or Brachyoxylon type.

\section{Discussion}

The genera of wood studied here are characteristic of the Neopaleozoic of Gondwanaland. The state of São Paulo represents their northernmost occurrence in Gondwanaland. Abietopitys has also been found in the Pennsylvanian Jejenes Formation in the state of S. Juan, in Argentina, where Pujana (2005) described Abietopitys petriellae, and in the Permian Formation Nueva Lubecka, in the province of Chubut, where Archangelsky (1960) described Abietopitys patagonica and Abietopitys crassiradiata. In Brazil, the genus has been found in other outcrops of the Irati Formation and in Serra Alta Formation (Mussa 1986; Merlotti 2009), and also in the Permian Karoo Supergroup of the Karoo Basin in South Africa (Mussa 1986).

The genera of Solenopitys and Atlanticoxylon are restricted to the Permian, with Solenopitys being more widely distributed in the southern part of Gondwanaland, from the Paraná Basin in the south of Brazil (Irati Formation; Mussa 1986) to the Falkland Islands (Mussa 1986), South Africa and Antarctica (Merlotti and Kurzawe 2011). Atlanticoxylon, on the other hand, was limited to the Paraná Basin (Irati Formation, Mussa 1986; Merlotti and Kurzawe 2011) and India (Guerra-Sommer et al. 2014).

Palaeoecological and taphonomic notes

Mussa (1982) suggested that the lacunose piths commonly observed in wood from the Irati Formation, such as those of Atlanticoxylon, may represent an adaptation to dry conditions, with the lacunae associated with increased aeration and water storage. The sclerenchyma also generally present in these woods, such as in A. bortoluzzii, would have provided support to compensate for the regions of the lacunae.

False growth rings, which are common in all the specimens described here, are another xeromorphic adaptation (Creber and Chaloner 1984). Periods of drought are related to less elongation of the leaves of Pinus resinosa and, consequently, to lower production of auxin (Larson 1963). The decrease in auxin would have led to less elongation of the tracheids themselves, which are what form the false ring. Periods of drought also affect the efficiency of auxin, as turgor is necessary for the normal elongation of the tracheids (Zahner 1968).
The presence of these anatomic features in the wood described here may be related to the depositional environment of the Irati Formation. As commented in the section "Geological Setting", the Assistência Member of the Irati Formation consists of a basal carbonate breccia containing evaporites, as well as beds of dolomite and stromatolites, all associated with relatively dry climates (Guerra-Sommer et al. 2014; Rohn et al. 2015, Calça et al. 2016). It must be emphasised, however, that the climatic conditions during the growth of these trees cannot have been extremely arid, since other plants also found in the Irati Formation developed relatively large trunks, with diameters between 20 to $60 \mathrm{~cm}$ for the specimens (CP1/20, CP1/ 266, CP1/ 271 and CP1/272).

The cylindrical morphology of the fossilised specimens indicates impregnation by silica before significant burial, probably concomitant with sedimentation (Buurman 1972). In the Irati Formation, the silicification process occurred due to the alkalinity conditions of the environment by the action of several factors, such as intense activity of microbial mats associated with hypersaline conditions in a restricted marginal environment (Calça and Fairchild 2012).

\section{Conclusions}

The three fossil wood specimens from the Irati Formation studied here reveal diverse primary xylem characteristics, reflected in the two different species and the form to which they have been assigned: Solenopitys paulistana Kräusel, Atlanticoxylon ibiratinum n. sp. and Abietopitys sp. Kräusel. The secondary xylem of these specimens shows two different patterns: that of the Brachyoxylon type, associated with the specimens included in S. paulistana and A. ibiratinum, and that of the Protobrachyoxylon or Brachyoxylon type, associated with the wood classified as Abietopitys sp. These genera have previously been reported in the Irati Formation, but from different localities.

Xeromorphic features observed in those specimens such as lacunose pith with groups of sclereids and false growth rings may be related to the depositional environment of the Irati Formation. Moreover, similar adaptations are also found in fossil wood from the Whitehill Formation of the Karoo Basin in Africa, which correlates with the Irati Formation, and from the Raniganj Formation in India, a slightly later chronostratigraphic formation (Guerra-Sommer et al. 2014). The specific factor that triggered the xeromorphy cannot as yet be determined, but the present study clearly provides more evidence of the dry conditions prevailing during the deposition of the Irati Formation.

Acknowledgements The authors would like to acknowledge the collaboration with Margarita Ricardi Torres (Botanical Garden Center, ULA, Mérida, Venezuela, in memoriam), Alexandra Crisafulli (Facultad de 
Ciencias Exactas y Naturales y Agrimensura, Universidad Nacional del Nordeste, Corrientes, Argentina) and an anonymous reviewer for the significantly improved quality of the paper.

Funding information The authors would like to thank the Brazilian National Council for Scientific and Technological Development (CNPq) and the Foundation for the Support of Research in the State of São Paulo (FAPESP) for the financial supports provided [(FAPESP Process 2009/ 10547-1 "Paleophytogeography and fossil woods from Paraná Basin during late Paleozoic") and (FAPESP 2013/11563-6 "Multi-source data integration for paleobotanical analysis of the Parana Basin, during Carboniferous and Permian times")].

\section{Compliance with ethical standards}

Conflict of interest The authors declare that they have no conflict of interest.

\section{References}

Amaral, S. E. (1971). Geologia e petrologia da Formação Irati (Permiano) no Estado de São Paulo. Boletim do Instituto de Geociências e Astronomia, 2, 3-82.

Bamford, M. K., \& Philippe, M. (2001). Jurassic-Early Cretaceous Gondwanan homoxylous woods: a nomenclatural revision of the genera with taxonomic notes. Review of Palaebotany and Palynology, 113, 287-297.

Buurman, P. (1972). Mineralization of fossil wood. Scripta Geologica, $12,1-43$.

Calça, C. P., \& Fairchild, T. R. (2012). Petrographic approach to the study of organic microfossils from the Irati Subgroup (Permian, Paraná Basin, Brazil). Journal of South American Earth Sciences, 35, 5161. https://doi.org/10.1016/j.jsames.2011.10.005.

Calça, C. P., Fairchild, T. R., Cavalazzi, B., Hachiro, J., Petri, S., Huila, M. F. G., \& Araki, K. (2016). Dolomitized cells within chert of the Permian Assistência Formation, Paraná Basin, Brazil. Sedimentary Geology, 335, 120-135. https://doi.org/10.1016/j.revpalbo.2016.03. 004.

Compania de Pesquisas de Recursos Minerais - CPRM. (2004). Carta Geológica do Brasil ao Milionésimo: sistema de informações geográficas-SIG, escala 1:1.000.000. Brasília, Ministério de Minas e Energia.

Cortez, I. C. S., Ricardi-Branco, F., \& León, Y. V. (2012). Permian bryophytes of Western Gondwanaland from Paraná Basin in Brazil. Palaeontology, 55(1), 229-241.

Creber, G. T., \& Chaloner, W. G. (1984). Influence of environmental factors on the wood structure of living and fossil trees. The Botanical Review, 50(4), 357-448.

Ferreira-Oliveira, L. G., \& Rohn, R. (2010). Leaiid conchostracans from the uppermost Permian strata of the Paraná Basin, Brazil: Chronostratigraphic and paleobiogeographic implications. Journal of South American Earth Sciences, 29(2), 371-380. https://doi.org/ 10.1016/j.jsames.2009.03.006

Gifford, E. M. E. M., \& Foster, A. S. (1989). Morphology and evolution of vascular plants (3rd ed.). New York: W. H. Freeman and Company.

Greguss, P. (1955). Identification of living gymnosperms on the basis of xylotomy. Identification of living gymnosperms on the basis of xylotomy. Akádemiai Kiádo, Budapest.

Guerra, M. (1975). Presença do gênero Polysolenoxylon na Formação Irati do Rio Grande do Sul. In Congresso Argentino de Paleontologia Y Bioestratigrafia (Vol. 1, pp. 371-400).
Guerra-Sommer, M., Degani-Schmidt, I., Mussa, D., Kavali, P. S., \& Shivanna, M. (2014). The stratigraphic significance of the Solenoid Complex in the Permian of Gondwana. Geologia USP: Série Científica, 14(2), 139-148.

Hachiro, J., Coimbra, A. M., \& Matos, S. L. F. (1993). O caráter cronoestratigráfico da unidade Irati. In Simpósio sobre cronoestratigrafia da Bacia do Paraná (Vol. 1, No. 1993, pp. 7274).

Hartig, A. (1848). Beitrage zur Geschichte der Pflanzen und zur Kenntniss der norddeutschen Braunkohlen-Flora. Bot. Ztg. (6), $185-190$

Holz, M., França, A. B., Souza, P. A., Iannuzzi, R., \& Rohn, R. (2010). A stratigraphic chart of the Late Carboniferous/Permian succession of the eastern border of the Paraná Basin, Brazil, South America. Journal of South American Earth Sciences, 29(2), 381-399. https://doi.org/10.1016/j.jsames.2009.04.004.

Kenrick, P., \& Crane, P. R. (1997). The origin and early diversification of land plants. A cladistic study (Vol. 560). Smithsonian Institute Press Washington DC.: A cladistic study. Smithsonian Institute Press.

Kräusel, R. (1928). Beiträge zur Kenntnis der Karruformation DeutschSüdwest-Afrikas (No. 20). Im Vertrieb bei der Preussischen Geologischen Landesanstalt.

Kräusel, R., \& Dolianiti, E. (1958). Gymnospermenhölzer aus dem Paläozoikum Brasiliensis. Palaeontographica Abteilung B, 115137.

Kulkarni, S., Maithy, P. C., \& Surange, K. R. (1971). On Barakaroxylon jhariense. The Palaeobotanist, 18, 305-308.

Larson, P. R. (1963). The indirect effect of drought on tracheid diameter in red pine. Forest Science, 9(1), 52-62.

Maniero, J. (1944). Dadoxylon whitei sp. n. Boletim da Faculdade de Filosofia Ciências e Letras, Universidade de São Paulo. Geologia, (45), 107-112.

Maniero, J. (1951). Prototaxopitys brasiliana gen. et sp. nov. - Madeira nova do Permiano Inferior. Anais da Academia Brasileira de Ciências, 23, 105-112.

Marguerier, J. (1973). Paleoxylologié du Gondwana African. Étude et affinités du Genre Australoxylon. Palaeontologica Africana, 16, $37-58$.

McNeill, J., Barrie, F. R., Buck, W. R., Demoulin, V., Greuter, W., Hawksworth, D. L., ... \& Prud'homme Van Reine, W. F. (2012). International Code of Nomenclature for algae, fungi and plants. Regnum vegetabile, 154.

Merlotti, S. (2009). Reavaliação taxonômica de lenhos das formações Irati e Serra Alta, Permiano da Bacia do Paraná, Brasil. Pesquisas em Geociências, 36, 11-21.

Merlotti, S., \& Kurzawe, F. (2011). Lenhos permianos da Bacia do Paraná, Brasil: síntese e revisão taxonômica. Gaea-Journal of Geoscience, 7(1), 19-33.

Milani, E. J., Faccini, U. F., Scherer, C. M., Araújo, L. M. D., \& Cupertino, J. A. (1998). Sequences and stratigraphic hierarchy of the Paraná Basin (Ordovician to Cretaceous), southern Brazil. Boletim IG-USP, Série Científica, 29, 125-173.

Milani, E. J., Melo, J. H. G., Souza, P. A., Fernandes, L. A., \& França, A. B. (2007). Bacia do Paraná. Boletim de Geociências da PETROBRÁS, 15(2), 265-287.

Mussa, D. (1974). Paleoxiloanatomia Brasileira II - Novo gênero de lenho fóssil da Formação Irati, Estado de São Paulo. Anais da Academia Brasileira de Ciências, 46, 617-634.

Mussa, D. (1978). Brasilestiloxylon e Solenobrasilioxylon, dois novos gêneros gondwânicos na formação Irati, Estado de São Paulo, Brasil. Boletim IG, 9, 118-127.

Mussa, D., 1982. [Lignitafofloras Permianas da Bacia do Paraná, Brasil (estados de São Paulo e Santa Catarina). Ph.D. Thesis. Instituto de Geociências, Universidade de São Paulo, São Paulo, Brazil. Unpublished.] Available at http://www.teses.usp.br/teses/ disponiveis/44/44132/tde-03082015-143416/en.php 
Mussa, D. (1986). As formas gondwânicas do Grupo Solenóide e sua distribuição estratigráfica. Anais da Academia Brasileira de Ciências, 58(1), 61-88.

Neregato, R., Souza, P. A. D., \& Rohn, R. (2008). Registros palinológicos inéditos nas formações Teresina e Rio do Rasto (Permiano, Grupo Passa Dois, Bacia do Paraná): implicações biocronoestratigráficas e paleoambientais. Pesquisas em Geociências, 35(2), 9-21.

Philippe, M. (2011). How many species of Araucarioxylon? Comptes Rendus Palevol, 10(2), 201-208.

Philippe, M., \& Bamford, M. K. (2008). A key to morphogenera used for Mesozoic conifer-like woods. Review of Palaeobotany and Palynology, 148(2), 184-207. https://doi.org/10.1016/j.revpalbo. 2007.09.004.

Pujana, R. R. (2005). Gymnospermous woods from Jejenes Formation, Carboniferous of San Juan, Argentina: Abietopitys petriellae (Brea and Césari) nov. comb. Ameghiniana, 42(4), 725-731.

Ricardi-Branco, F., de Caires, E. T., \& Silva, A. M. (2009). Excelente registro do litoral do mar permiano Irati, Bacia do Paraná, Brasil. In M. Winge, C. Schobbenhaus, M. Berbert-Born, E.T. Queiroz, D.A. Campos, C.R.G. Souza, \& A. C. S. Fernandes (Eds.) Sítios
Geológicos e Paleontológicos do Brasil (pp. 371-380). Vol. II. Brazília: CPRM.

Richter, H. G., Grosser, D., Heinz, I., \& Gasson, P. E. (2004). IAWA list of microscopic features for softwood identification. IAWA Journal, $25,1-70$.

Rohn, R., Fairchild, T. R., \& Dias-Brito, D. (2015). Microbialitos de Santa Rosa de Viterbo, Estado de São Paulo, Formação Irati, Permiano Inferior, Bacia do Paraná. In R. Rohn, T. R. Fairchild, \& D. Dias-Brito (Eds.), Microbialitos do Brasil do Pré-Cambriano ao Recente: um atlas. UNESP - IGCE - UNESPetro, 1 (pp. 248-269). Brazil: Rio Claro.

Santos, R. V., Souza, P. A., de Alvarenga, C. J. S., Dantas, E. L., Pimentel, M. M., de Oliveira, C. G., \& de Araújo, L. M. (2006). Shrimp U-Pb zircon dating and palynology of bentonitic layers from the Permian Irati Formation, Paraná Basin, Brazil. Gondwana Research, 9(4), 456-463.

Stewart, W. N., \& Rothwell, G. W. (1993). Paleobotany and the evolution of plants. Cambridge University Press.

Zahner, R. (1968). Water deficits and growth of trees. Water Deficits and Plant Growth, 2, 191-254. 